\title{
Proficiency of Maritime English course: An investigation in Istanbul, Turkey
}

\author{
Sercan Saray ${ }^{1}$, Tanzer Satır ${ }^{1}$, Neslihan Doğan-Sağlamtimur ${ }^{2 *}$ \\ ${ }^{1}$ Department of Maritime Transportation and Management Engineering, Istanbul Technical University (ITU), Tuzla-Istanbul, Turkey \\ ${ }^{2}$ Department of Environmental Engineering, Niğde Ömer Halisdemir University, Niğde, Turkey
}



Keywords: Communication, Education, Maritime English course, Statistical analysis, Vocational high school

\section{Introduction}

Our world has undergone major changes in the past century. The foremost striking among these changes can be seen as the evacuation of borders between nations with the developing innovation. A few professions within the world and the trade lines joined to it are more influenced by these changes than others. One of these business lines is undoubtedly the maritime profession. Considering that approximately $71 \%$ of the world is covered with seas, the importance of the seas in the history of civilizations and countries is revealed to be undeniable. It is seen that $75 \%$ of the world's population lives in regions close to the sea, $85 \%$ of the countries' freight and $90 \%$ of their oil transportation by sea [1]. Therefore, effective and safe realization of the sea transportation which is vital factor of the global economy, is of great importance. International Maritime

This work is licensed under a Creative Commons Attribution License (https://creativecommons.org/licenses/by/4.0/ ) that allows others to share and adapt the material for any purpose (even commercially), in any medium with an acknowledgement of the work's authorship and initial publication in this journal. 
Organisation (IMO) (2005) has reported that by far majority of accidents at sea are caused by human error, and one of the main causes of these accidents and incidents is due to poor standards of Maritime English [2]. For that reason, the importance of Maritime English education in maritime institutions cannot be denied in order to improve the quality of maritime education and prevent possible accidents.

Communication is an important part of human interaction. The problems of misunderstanding or lack of communication in our daily lives can cause simple troubles but the mistakes made by the personnel on board can cause major economic losses and fatal consequences. Today, ship personnel from different countries work for the same purposes. $28.5 \%$ of the ship's personnel working in world trade fleets consist of 2 nations, $17 \%$ of consist 3 nations, $9.70 \%$ consist of 4 nations, and the $10.60 \%$ consist 5 or more nations Fig. 1. Only $30.4 \%$ consists of one nation [3]. These numbers tell us that a common language should be given importance to ensure effective communication at sea.

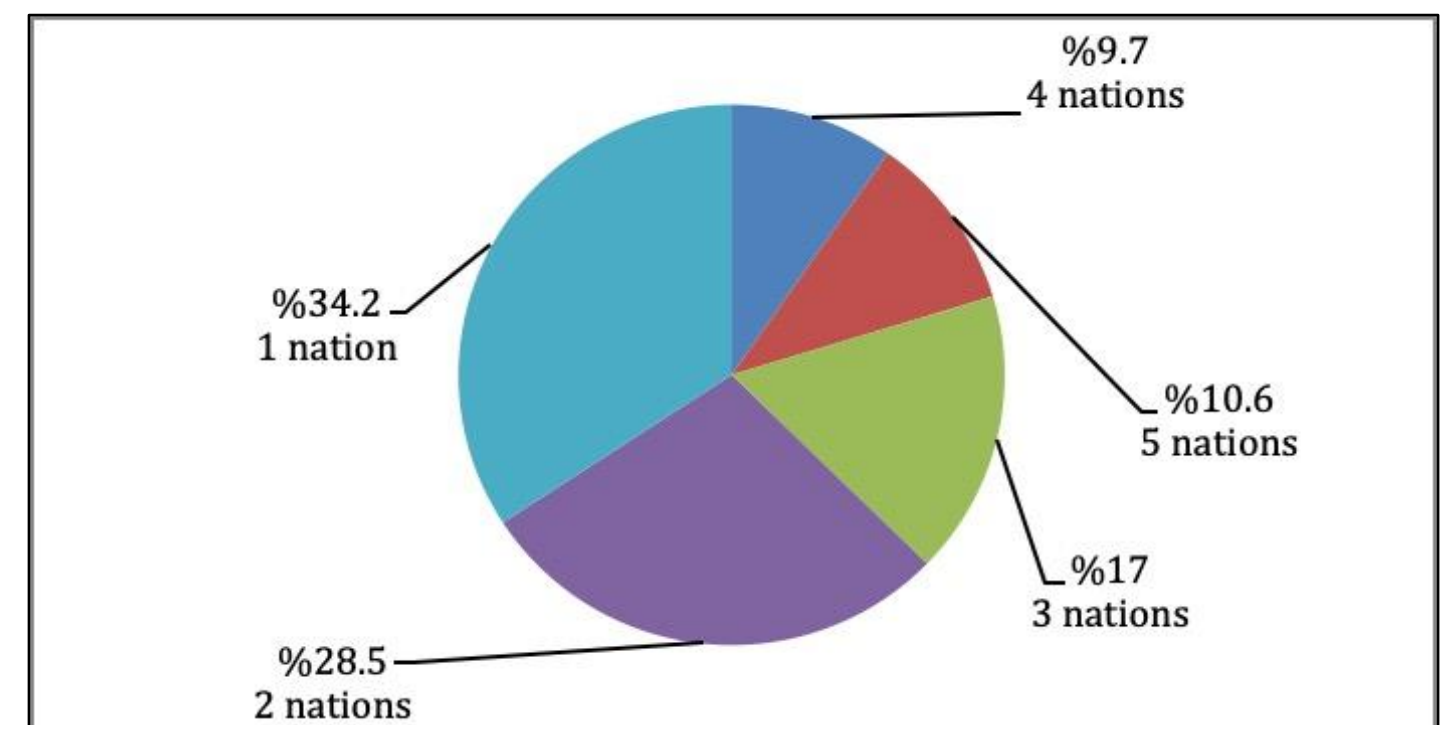

Figure 1. Percentage of ships using mixed crews of the world trade fleet

English, which has the highest level of prevalence as a world language, has been accepted as the official language for seafarers in order to minimize the problems of IMO and the problems arising from the lack of a common communication channel at sea. As a result of the studies carried out, Maritime English has brought along the process that allows the crew to work in the sea to be formed in the light of common terms and expressions.

\subsection{Literature review}

Some studies on maritime education in vocational high schools and Maritime English are given in the following text. In study from 2007 researchers determined the competencies and standards of a good Maritime English instructor that should have in today's conditions. They categorized and described the various types of Maritime English instructors presently employed at higher Maritime Education and Training institutions worldwide, defined the requirements regarding their professional qualifications in the areas of applied linguistics, methodology and the minimum maritime background knowledge demanded by the relevant international legislation, and thus provided a guideline for management and prospective instructors [4].

Study from 2009 explored the causes of accidents on ships and port operations in Maritime English to improve safety standards at sea and ports. They showed the importance of Maritime English proficiency in effective communication [5].

Karakaya examined the process of maritime education from the Ottoman Empire until today in the study titled "The Historical Development of Merchant Marine Education in the Republic Period" [6]. Pritchard categorized and divided English used in maritime related business and operations into sections in his study. In the study, he determined technical terms that seafarers should know at a minimum level in Maritime English. $\mathrm{He}$ also determined a framework of important terms in maritime English teaching [7]. Trenkner and Cole categorized English language skills that seafarers should have according to the current IMO International Convention on Standards of Training, Certification and Watchkeeping (STCW) and classified them according 
to seafarer competencies. With regard to Maritime English, this study observed IMO's decision-making process, identified and commented on the new provisions in the Convention and the existing provisions [8]. Nas and Celik evaluated maritime higher education institutions providing education at the undergraduate level with fulltime employed academicians (with maritime background) have been evaluated via the data obtained using the methods of statistical analysis. indicated that the most important problems encountered in the maritime education and training institutions are about the inadequate numbers of trainers who have worked in the sea before [9]. In 2015 researchers evaluated the Maritime English education in China and showed the shortcomings of education and what should be. As a result of the study, it was revealed that education based on practical language skills should be focused on [10]. Koca analyzed the quantitative situation of higher education and secondary education institutions that train seafarers today and made suggestions for the improvement of education in his study named "An Evaluation on Maritime Education" [11]. Altuntaş made a comparison between the interactive methods of Maritime English and traditional language teaching methods in the study named "Testing the Effectiveness of using Interactive Learning Tools for Teaching Maritime English". It has been demonstrated that interactive learning methods are more successful than traditional English lessons [12]. Study from 2017 examined the variables affecting English learning achievement of marine college students within the framework of 4 factors that are supposed to be related to English learning [13]. In 2018 Dirgeyasa determined the Maritime English learning materials based on the language competencies that Indonesian Maritime Academy students need most in their maritime life [14]. In 2019 Chen et al. examined the feasibility of Maritime English teaching with the sea simulator and explained it in detail according to the functions and features of the sea simulator with the teaching scheme created [15]. The study from 2020) tried to define how a good Maritime English instructor should be from a student perspective in their study [16].

As a result of the literature review, the lack of a study on the efficiency and deficiencies of the Maritime English course given in the context of maritime vocational high schools in Turkey and the importance of language proficiency in terms of the maritime profession constitute the main motivation of the present study. The aims of this study are (i) to determine the attitudes of graduates against to English and their needs about English in shipping world, (ii) to identify potential problems in English and Maritime English teaching at the vocational high school level maritime training and education in Turkey, (iii) to identify the necessary innovations for improving quality of education.

\subsection{Brief explanation of maritime education in Turkey}

Turkey is one of the few countries in the world that educates many seafarers. According to data of the Ministry of Transport and Infrastructure (Turkey), number of active seamen in Turkey is 116.878. There are 50 maritime vocational high schools depend on Ministry of National Education (Turkey) and 32 associate degree and 29 bachelor degree programs which depend on at the higher education institutions in the Turkey as seen in Table 1. Apart from these, there are 34 Special Maritime Training Centers [17].

$\underline{\text { Table 1. Maritime education and training institutions in Turkey }}$

\begin{tabular}{ll}
\hline Maritime Education Institutions & Number \\
\hline High Schools & 50 \\
Associate Degree Programs & 32 \\
Bachelor's Degree Programs & 29 \\
Special Maritime Training Centers & 34 \\
Total & 145 \\
\hline
\end{tabular}

In Turkey, maritime vocational and technical high schools constitute the second level in maritime education and training. Anatolian maritime vocational and technical high schools are authorized with results of inspections which made by the Ministry of Transport and Infrastructure. This ministry carries out the inspections of the trainings in accordance with the criteria specified in Standards of Training, Certification and Watchkeeping for seafarers (STCW). Some of these educational institutions provide deck officer degree and engine officer degree training according to STCW Regulation II/3, and III/3 while others offer restricted officer training according to II/1 and III/1 in STCW [18]. 


\subsection{English education in maritime vocational high schools}

The implementation of foreign language education in schools in Turkey depends on the Language Education and Training Act that was adopted in 1983. With the reform of education in 1997, compulsory education has been increased to 8 years, and English course has been introduced from the $4^{\text {th }}$ year to the compulsory education since 1997-1998. In 2011, with the transition to the 4+4+4 education system, English course was started to be offered from the $2^{\text {nd }}$ year [19], [20].

Before the education reform in 2004, Foreign Language lessons were 24 hours in maritime training institution. There were mandatory English preparation classes for marine students. It changed many times until now. According to the last published framework of teaching English Lessons, there are 5 hours a week in $9^{\text {th }}$ grade; 2 hours a week in $10^{\text {th }}, 11^{\text {th }}$ and $12^{\text {th }}$ grades respectively. The Table 2 below shows the variation of the general English education given in maritime vocational high schools by years [21].

Table 2. English course hours by years in maritime vocational high schools

\begin{tabular}{cccccc}
\hline Years & $9^{\text {th }}$ Grade & $10^{\text {th }}$ Grade & $11^{\text {th }}$ Grade & $12^{\text {th }}$ Grade & Total \\
\hline 2007 & 3 & 3 & - & - & 6 \\
2011 & 3 & 2 & 2 & - & 7 \\
2014 & 6 & 4 & 4 & 4 & 18 \\
2019 & 5 & 2 & 2 & 2 & 11 \\
\hline
\end{tabular}

When the 2019's statistics are examined, the hour of English lessons taken by the ship's officers is 11 hours in total 4 years of education. When English education given in maritime vocational high schools in Turkey is examined, it can be seen that there is an approach based on traditional language teaching methods in the foreign language program in force until 2006. If we analyze the curriculum that has been in force since May 2006, it is seen that serious steps have been taken towards abandoning this traditional approach [22].

\subsection{Maritime English courses in maritime vocational high schools}

In Turkey, Ministry of National Education has to prepare contents of Maritime English courses according to the Seafarers Training and Examination Directive which is published by the Ministry of Transport and Infrastructure. It has planned 2 hours for deck and engine officer candidates for 2019-2020 academic years. It is expected to learn 7 modules for both deck and engine officers in 2 hours per week. These 7 modules are;

- Ship structure in English

- Advanced maritime education and maritime law in English

- Maritime management and ship inspection in English

- Uses terms related to ship engines and operating systems English

- Standard marine communication phrases (SMCP)

- Terms of deck and maneuvering in English

- Ship electronics and communication in English [21].

\section{Materials and methods}

\subsection{Participants and materials}

Participants were selected among the individuals who have been educated in the maritime vocational high schools of Istanbul district and they had different sea experience periods and different English skills as a year.

\begin{tabular}{lcc}
\multicolumn{3}{c}{ Table 3. Distribution of participants by gender status } \\
\hline Gender & Frequency & $\%$ \\
\hline Male & 177 & 87.6 \\
Female & 25 & 12.4 \\
Total & 202 & 100 \\
\hline
\end{tabular}

A total of 202 participants participated in the study is given in Table 3. There are 202 participants in total. 25 of them $(12.4 \%)$ are female and 177 of them $(87.6 \%)$ are male. 
Table 4. Distribution of participants by educational status

\begin{tabular}{lcc}
\hline Education & Frequency & $\%$ \\
\hline High school degree & 119 & 58.9 \\
Associate degree & 46 & 22.8 \\
Bachelor's degree & 31 & 15.3 \\
Graduates degree & 6 & 3.0 \\
Total & 202 & 100.0 \\
\hline
\end{tabular}

It is seen Table 4 that the majority (n:199, 58.9\%) of the participants are high school graduates. 46 of the participants (22.8\%) are associate degree, 31 of them (15.3\%) are undergraduate and 6 of them (3.0\%) are graduate.

Sea experience of the participants (in total) seems to be almost evenly distributed between 0-12 months (n:83, $41.1 \%)$ and 10 years and above (n:70, 34.7\%) as presented in Table 5. In addition, 48 of participants (23.8\%) has 1-10 years sea experience.

Table 5. Distribution of participants according to sea experience

\begin{tabular}{lcc}
\hline Duration of sea experience & Frequency & $\%$ \\
\hline 0-12 months & 83 & 41.29 \\
1-3 years & 37 & 18.41 \\
3-5 years & 4 & 1.99 \\
5-10 years & 7 & 3.48 \\
10 years and above & 70 & 34.83 \\
Total & 201 & 100 \\
\hline
\end{tabular}

In this study, a questionnaire was conducted as a data collection tool. The creation of the survey was carried out from September to October 2019, and the collection of responses was made between October and December 2019. In order to make it easier to reach the participants in this study, the data has been collected online. It took about 10 minutes to fill the scales. The survey consists of 35 questions and is a Likert type scale ranging from 1 (strongly disagree) to 5 (strongly agree). The scale was developed during this research and the internal reliability of 35 items was found to be good (Cronbach $\alpha=0.82$ ).

\subsection{Statistical analyses}

SPSS 22 program was used in the analysis of the data. Firstly, reliability analysis was applied to the questionnaire created in this research without separating its factors, and then Descriptive Factor Analysis was applied to determine the factor structure. After the conceptual level of interrelated items were collected under the same factor, a reliability test was performed again. In the study; t-test was used to evaluate numerical data between two independent groups and One-Way Analysis of Variance (ANOVA) Test was used to evaluate numerical data between more than two independent groups [23]. After the One-Way ANOVA Test, Tukey test was used as a complementary Post-Hoc analysis to determine the differences. Pearson correlation method was used to evaluate the continuous numerical variables used in the research.

\section{Results}

As a result of the factor analysis as shown in Table 6, it was seen that the questions can be collected under 4 factors and the analysis continues in this way. Ten questions were collected under the first factor and the name of this factor was determined as attitude towards general and Maritime English. Nine questions were collected under the second factor and the name of this factor was determined as the requirements for the improvement of the received education. Eight questions were collected under the third factor and the name of this factor was determined as problems related to general English and Maritime English education. Eight questions were collected under the fourth factor and the name of this factor was determined as the adequacy of the education.

Table 6. Factor statistics

\begin{tabular}{lcccc} 
Factors & Mean & Standard error & Frequency & Reliability \\
\hline Total & 3.5833 & .40338 & 199 & 0.820 \\
\hline
\end{tabular}




\begin{tabular}{lllll}
\hline Attitudes towards Maritime English education & 4.3864 & .64202 & 199 & 0.918 \\
What to do for improving education & 4.0765 & .57652 & 199 & 0.795 \\
$\begin{array}{l}\text { Industry-based problems of English education in } \\
\text { maritime vocational high schools }\end{array}$ & 3.3926 & .74101 & 199 & 0.742 \\
Adequacy of education received & & & & \\
\hline
\end{tabular}

Independent sample t-test given in Table 7 was used to evaluate the relationship between gender and factors. There was a significant difference between the problem definition factor and gender $(\mathrm{p}=0.02)$. According to results of the test, female graduates $(\mathrm{M}=3.73 \pm 0.68)$ identified more educational problems than male graduates $(\mathrm{M}=3.35 \pm 0.74)$.

Table 7. Distribution of the average scores of participants on Maritime English education by gender

\begin{tabular}{lccccc}
\hline Factors & Gender & $\mathrm{N}$ & Mean & S.D. & $\mathrm{p}$ \\
\hline Attitudes towards Maritime English education & Male & 176 & 4.3648 & .66074 & 0.252 \\
& Female & 24 & 4.5250 & .46180 & \\
& & & & & \\
What to do for improving education & Male & 176 & 4.0663 & .58448 & 0.385 \\
& Female & 25 & 4.1733 & .50520 & \\
& & & & & \\
Industry-based problems of English education & Male & 176 & 3.3587 & .74690 & 0.02 \\
in maritime vocational high schools & Female & 25 & 3.7300 & .68814 & \\
& & & & & \\
Adequacy of education received & Male & 175 & 2.2386 & .65834 & 0.141 \\
& Female & 25 & 2.0350 & .53341 & \\
\hline
\end{tabular}

The One-Way ANOVA Test was used to determine the relationship between the participants' evaluations of the factors and their educational status. As seen in Table 8, there is a significant relationship between education level and personal English proficiency [F (3.198)=11.782; $\mathrm{p}=0.000]$.

Table 8. The distribution of the average scores of the participants on Maritime English education and personal English proficiency by level of education

\begin{tabular}{lcccccc}
\hline Factors & $\begin{array}{c}\text { Education } \\
\text { degrees }\end{array}$ & N & Mean & S.D. & p & $\begin{array}{c}\text { Post-Hoc } \\
\text { Tukey HSD } \\
\text { Test (sig.) }\end{array}$ \\
\hline Attitudes towards Maritime English & $\mathrm{A}$ & 119 & 4.3689 & .64450 & 0.585 & \\
education & $\mathrm{B}$ & 46 & 4.3391 & .77359 & & \\
& $\mathrm{C}$ & 31 & 4.4552 & .39963 & & \\
& $\mathrm{D}$ & 6 & 4.6833 & .35449 & & \\
What to do for improving education & $\mathrm{A}$ & 118 & 4.0876 & .60053 & 0.935 & \\
& $\mathrm{~B}$ & 46 & 4.0507 & .58359 & & \\
& $\mathrm{C}$ & 31 & 4.0681 & .40438 & & \\
Industry-based problems of English & $\mathrm{D}$ & 6 & 4.2037 & .84741 & & \\
education in maritime vocational high & $\mathrm{A}$ & 118 & 3.4322 & .77429 & 0.282 & \\
schools & $\mathrm{B}$ & 46 & 3.5027 & .64737 & & \\
& $\mathrm{C}$ & 31 & 3,1976 & .75331 & & \\
Personal English proficiency & $\mathrm{D}$ & 6 & 3.1875 & .87589 & & \\
& & & & & & \\
& $\mathrm{~A}$ & 119 & 1.882 & .5848 & 0.000 & \\
& $\mathrm{~B}$ & 46 & 2.000 & .6667 & & $\mathrm{C}>\mathrm{A}(0.00)$ \\
\hline
\end{tabular}


Adequacy of education received

$\begin{array}{ccccc}\text { A } & 118 & 2.2638 & .62421 & \\ \mathrm{~B} & 46 & 2.1793 & .80219 & 0.930 \\ \mathrm{C} & 30 & 2.0875 & .44425 & \\ \mathrm{D} & 6 & 2.1042 & .62957 & \end{array}$

A: High School, B: Associate Degree, C: Bachelor's Degree, D: Graduates Degree

The Post-Hoc Tukey Test was applied in order to understand from which groups the difference between groups originated as seen in Table 8. Accordingly, undergraduate graduates $(M=1.48 \pm 0.50)$ have a significantly higher average in the field of personal language proficiency than high school graduates $(\mathrm{M}=2.11 \pm 0.58)(\mathrm{p}=0.000)$.

The results of the relationship between the participants' factor data obtained from this study and the marine experience can be seen in Table 9. As the sea experience increases, participants' problem identification scores decrease. Particularly, the high scores given by the participants who have marine service between 0-12 months and who have just graduated from the school on the problem definition questions related to the education provided were remarkable. There is a meaningful relationship between the factor points given to the problem of Maritime English education with sea experience $[\mathrm{F}(4.196)=6.921 ; \mathrm{p}=0.000]$ and personal English proficiency $[\mathrm{F}(4.197)=8.201 ; \mathrm{p}=0.000]$.

Table 9. The distribution of the average scores of the participants on Maritime English education and personal English proficiency according to their sea experience

\begin{tabular}{|c|c|c|c|c|c|c|}
\hline Factors & Sea experience & $\mathrm{N}$ & Mean & S.D. & $\mathrm{p}$ & $\begin{array}{c}\text { Post-Hoc Tukey } \\
\text { HSD } \\
\text { Test (sig.) }\end{array}$ \\
\hline Attitudes towards & A & 82 & 4.3671 & 68061 & \multirow{5}{*}{0.612} & \\
\hline Maritime English & B & 36 & 4.3000 & 66419 & & \\
\hline \multirow[t]{3}{*}{ education } & $\mathrm{C}$ & 4 & 4.2250 & .57373 & & \\
\hline & D & 7 & 4.6857 & .23401 & & \\
\hline & $\mathrm{E}$ & 71 & 4.4254 & .61452 & & \\
\hline \multirow{5}{*}{$\begin{array}{l}\text { What to do for } \\
\text { improving education }\end{array}$} & A & 82 & 4.0068 & .66170 & \multirow{5}{*}{0.152} & \\
\hline & B & 37 & 3.9910 & .65754 & & \\
\hline & $\mathrm{C}$ & 4 & 3.9722 & .43862 & & \\
\hline & $\mathrm{D}$ & 7 & 4.3810 & .20141 & & \\
\hline & E & 70 & 20.97 & 4.10 & & \\
\hline Industry-based & A & 82 & 3.6540 & .71936 & \multirow{5}{*}{0.02} & \\
\hline problems of English & B & 37 & 3.5101 & .82410 & & \\
\hline education in maritime & $\mathrm{C}$ & 4 & 3.4063 & .71716 & & \\
\hline vocational high & $\mathrm{D}$ & 7 & 3.4107 & .63621 & & $\mathrm{E}>\mathrm{A}(0.00)$ \\
\hline schools & $\mathrm{E}$ & 71 & 3.0616 & .63029 & & \\
\hline \multirow{5}{*}{$\begin{array}{l}\text { Adequacy of } \\
\text { education received }\end{array}$} & A & 81 & 2.3086 & .70519 & \multirow{5}{*}{0.093} & \\
\hline & B & 37 & 1.9932 & .68208 & & \\
\hline & $\mathrm{C}$ & 4 & 2.4688 & .55316 & & \\
\hline & $\mathrm{D}$ & 7 & 1.9464 & .49401 & & \\
\hline & $\mathrm{E}$ & 71 & 2.2306 & .54676 & & \\
\hline Personal & A & 83 & 1.759 & .6650 & \multirow{5}{*}{0.000} & \\
\hline English & B & 37 & 2.108 & .6139 & & \\
\hline \multirow[t]{3}{*}{ proficiency } & $\mathrm{C}$ & 4 & 2.250 & .5000 & & \\
\hline & D & 7 & 2.571 & .5345 & & $\mathrm{D}>\mathrm{A}(0.06)$ \\
\hline & $\mathrm{E}$ & 71 & 2.239 & .5200 & & $E>A(0.00)$ \\
\hline
\end{tabular}

A: 0-12 Months, B: 1-3 Years, C: 3-5 Years, D: 5-10 Years, E: 10 Years or above 
Post-Hoc Tukey test was applied in order to understand from which groups the difference between groups regarding the problems related to Maritime English education originated, as presented in Table 9. There was a significant difference between $0-12$ months of sea experience $(\mathrm{M}=3.65 \pm 0.72)$ and participants with 10 years of experience $(\mathrm{M}=3.06 \pm 0.63)(\mathrm{p}=0.000)$. According to the Post-Hoc Tukey test results on personal English proficiency, those with a sea service between 0-12 months $(\mathrm{M}=1.75 \pm 0.65)$ and those with a sea experience between 5-10 years $(M=2.57 \pm 0.53)$, a significant difference was found $(\mathrm{p}=0.06)$. Similarly, there was a significant difference between $0-12$ months of sea experience $(M=1.75 \pm 0.65)$ and participants with more than 10 years of sea experience $(\mathrm{M}=2.23 \pm 0.50)(\mathrm{p}=0.00)$. There was no statistically significant result in this context between other variables and groups $(\mathrm{p}>0.05)$.

In this study, Pearson correlation was used for evaluating the relationship between multiple numerical values. As seen the results of the correlation analysis in Table 10, there was no significant relationship between the attitudes towards Maritime English (Factor 1) factor, English learning time and the age of the participants. In addition, there was a significant relationship between attitude factor and problem definition (Factor 3) and the factor needed to increase the level of education (Factor 2). Accordingly, more problems were identified in education with those who gave more importance to the necessity of English than others $(r=0.339, p=0.00)$. A positive correlation was observed between the factor (Factor 2) required for the improvement of education and the problem identification factor $(\mathrm{r}=0.423, \mathrm{p}=0.00)$. In addition, a positive correlation was observed between the requirements factor for improving education and English learning time $(r=0.161, p=0.42)$ and the age of the participants $(\mathrm{r}=0.159, \mathrm{p}=0.33)$. A negative correlation was found between problem identification (Factor 3 ) scores and English learning times $(r=-0.205, p=0.09)$ and the age of the participants $(r=-0.285, p=0.00)$.

\begin{tabular}{|c|c|c|c|c|c|c|c|}
\hline Factors & & Factor 1 & Factor 2 & Factor 3 & Factor 4 & $\begin{array}{l}\text { English } \\
\text { learning } \\
\text { time }\end{array}$ & Age \\
\hline \multirow[t]{3}{*}{ Factor 1} & $r$ & 1 & $.443^{* *}$ & $.339^{* * *}$ & $\begin{array}{l}-.060 \\
\end{array}$ & .145 & .117 \\
\hline & Sig. & & .000 & .000 & .399 & .067 & .121 \\
\hline & $\mathrm{N}$ & 200 & 199 & 199 & 199 & 159 & 178 \\
\hline \multirow[t]{3}{*}{ Factor 2} & $\mathrm{r}$ & $.443^{* *}$ & 1 & $.423^{* *}$ & -.096 & $.161^{*}$ & $.159^{*}$ \\
\hline & Sig. & .000 & & .000 & .176 & .042 & .033 \\
\hline & $\mathrm{N}$ & 199 & 201 & 201 & 200 & 160 & 179 \\
\hline \multirow[t]{3}{*}{ Factor 3} & $\mathrm{r}$ & $.339^{* *}$ & $.423^{* *}$ & 1 & -.047 & $-.205^{* *}$ & $.285^{* *}$ \\
\hline & Sig. & .000 & .000 & & .505 & .009 & .000 \\
\hline & $\mathrm{N}$ & 199 & 201 & 201 & 200 & 160 & 179 \\
\hline \multirow[t]{3}{*}{ Factor 4} & $\mathrm{r}$ & -.060 & -.096 & -.047 & 1 & -.114 & -.116 \\
\hline & Sig. & .399 & .176 & .505 & & .154 & .123 \\
\hline & $\mathrm{N}$ & 199 & 200 & 200 & 200 & 159 & 178 \\
\hline English & $\mathrm{r}$ & .145 & $.161 *$ & $-.205^{* *}$ & -.114 & 1 & $.652 * *$ \\
\hline learning & Sig. & .067 & .042 & .009 & .154 & & .000 \\
\hline Time & $\mathrm{N}$ & 159 & 160 & 160 & 159 & 161 & 151 \\
\hline \multirow[t]{3}{*}{ Age } & $\mathrm{r}$ & .117 & $.159 *$ & $-.285^{* *}$ & -.116 & $.652 * *$ & 1 \\
\hline & Sig. & .121 & .033 & .000 & .123 & .000 & \\
\hline & $\mathrm{N}$ & 178 & 179 & 179 & 178 & 151 & 180 \\
\hline
\end{tabular}

\section{Discussion}

When the findings of the study were examined, it was seen that as the sea experience of the participants increased, their personal English proficiency levels increased. According to Franceshi seafarers are exposed to English not only in the ship but also in ship-to-land communications, and every environment of their work area provides an important practice of the language [24]. In this sense, the survey findings that revealed the practical insufficiency and the lack of interactive teaching methods in education are consistent with other 
studies which showing the importance of speaking and listening skills in language learning [7], [12]. When the curriculum published by the Ministry of National Education for maritime vocational high schools is examined, it is seen that the education of Maritime English is grammatical [21]. It is thought that this situation may cause practical applications to be overshadowed by in-class applications.

The vast majority of the participants stated that the qualifications of the educators who attended the course were low for the learning of the course (in terms of increasing motivation to the course) and the sea experience. The findings related to the problems of seafarer educators are in line with the findings of studies which investigated the problems in maritime vocational high schools [25], [26].

Although there are studies examining the problems of high schools providing maritime education in the field, the study is important in terms of guiding for future studies, since there is no study and measurement tool on the language proficiency of seafarers in maritime vocational high schools that provide maritime education. Besides, due to the fact that the questionnaire is applied only to those graduated from maritime vocational high schools in Istanbul, it is difficult to generalize the results all over Turkey. In further studies, a survey with using larger sample number of samples and which will be held in all provinces across Turkey could make it possible to get more reliable results concerning the general.

\section{Conclusion}

When the answers given to the questions are evaluated, it is seen that the participants are largely aware of the importance of professional English for the maritime profession. On the contrary, the answers given to the questions that constitute the adequacy factor of the education received constituted the question group with the lowest average score. It is seen that the participants generally evaluate the proficiency level of the education received as average and below. The majority of participants stated that the English education they received in primary education does not constitute a sufficient basis for Maritime English education at high school level. Also, the fact that most of the graduates find the lecture hours insufficient shows that it would be beneficial to bring the preparatory class, which used to exist in maritime vocational high schools. In the case that the preparatory class cannot be applied to all maritime vocational high schools, it is considered that students who choose the maritime department will be given a separate language exam in this field, determining their level of readiness and registering accordingly will improve the quality of their professional English lessons. One of the biggest problems revealed by the survey results is that the education is inadequate in practical terms. In order to eliminate the lack of practical training, it is considered that instead of the common Maritime English curriculum given in all branches under the maritime field, it would be appropriate to develop the curriculum to include the branches' own skills and the education curriculum offered by the Ministry of National Education of Turkey should be revised to include more practical applications. Besides, as stated in the survey results, it is thought that the maritime English educators with sea experience will increase the motivation of the students. Programs sourced from the field need to be reorganized. Also, it will be beneficial to rearrange the requirements of the seafarer educators for giving English lessons.

\section{References}

[1] O. Cetin, "Denizcilik Sektöründe Mukayeseli Bir Model," Güvenlik Stratejileri Dergisi, vol. 5, no. 10, pp. 35-58, 2009.

[2] R. Ziarati, "Safety at Sea-Applying Pareto Analysis." Proceedings of World Maritime Technology Conference WMTC 06, Queen Elizabeth Conference Centre, 2006.

[3] A.D. Lane and E. Kahveci, "The Formation and Maintenance of Transnational Seafarer Communities," in Economic and Social Research Council, Cardiff University, 2002.

[4] C. Cole, B. Pritchard, and P. Trenkner, "Maritime English Instruction-Ensuring Instructors' Competence," Ibérica, Revista de la Asociación Europea de Lenguas Para Fines Específicos, vol. 14, pp.123-147, 2007.

[5] R. Ziarati, M. Ziarati, and B. Çalbaş, "Improving Safety at Sea and Ports by Developing Standards for Maritime English”, in Bridge Conference, Finland, 2009.

[6] M.M. Karakaya, "Cumhuriyet Döneminde Ticari Denizcilik Eğitiminin Tarihsel Gelişimi (1923-1981)", M.S. Thesis, Istanbul University, Istanbul, Turkey, 2011.

[7] B. Pritchard, "Minimum (Technical) Vocabulary-Some Issues in Maritime English,” Vol 1, No.1, pp2-20, 2011.

[8] P. Trenkner and C. W. Cole, "The STCW Manila Amendments and their Impact on Maritime English," Universitatii Maritime Constanta, Analele, vol. 13, no.17, pp. 239, Constanta, 2012. 
[9] S. Nas, and B. Çelik, "Türkiye'deki Denizcilik Eğitimi Veren Kurumların Akademisyen Profili," Journal of ETA Maritime Science, vol. 1, no. 1, pp. 7-14, 2013.

[10] L. Fan, J. Fei, U. Schriever and S. Fan, "A Review of Maritime English Education and Training on China in Comparison with Other Top Suppliers of Seafarers," Asia-Pacific Journal of Marine Science\&Education, vol. 5, no. 2, pp. 22-38, 2015.

[11] Y.N. Koca, "Türkiye'de Denizcilik Eğitimi Üzerine Bir Değerlendirme," in Sosyal ve Beşeri Bilimlere Küresel Yaklaşımlar, Ed. Cem Can and Abdurrahman Kilimci, Detay Yayınc1lık, 2016.

[12] S. Altuntaş, "Testing the Effectiveness of using an Interactive Learning Tool to Teach English for Maritime Purposes,” M.S. Thesis, Karadeniz Teknik University, Trabzon, Turkey, 2016.

[13] S.A. Gani and R. M. Adnansyah, "Factors Affecting Maritime Students' Achievements in Maritime English," English Education Journal, vol. 8, no. 3, pp. 259-274, 2017.

[14] I.W. Dirgeyasa, "The Need Analysis of Maritime English Learning Materials for Nautical Students of Maritime Academy in Indonesia Based on STCW'2010 Curriculum," English Language Teaching, vol. 11, no. 9, pp. 41-47, 2018.

[15] J. Chen, X. Ran, D. Liu, S. Ying and Y. Jin, "Maritime English Teaching with Marine Simulator," In IMLA International Maritime English Conference, pp. 13, September 2019.

[16] L.P Anggraini, E. Ernis, and J. M. Jelenska, "Students' Perceptions towards Ideal Maritime English Teacher," Biormatika : Jurnal Ilmiah Fakultas Keguruan Dan Ilmu Pendidikan, vol. 6, no. 2, pp. 29-35, 2020.

[17] Deniz Bülten, "DTO, Denizcilik Sektör Raporunu Yayınladı" https://www.denizbulten.com/haber-dtodenizcilik-sektor-raporunu-yayinladi-21879.html (accessed: Dec. 19, 2020)

[18] GAEBS (Seaman Training Information System). https://gbs.uab.gov.tr/ (accessed: Dec. 19, 2020).

[19] F. Özbay. “Türkiye'de Yabanc1 Dil Öğretiminin Tarihi Geçmişi ve Türkiye'nin Günümüzdeki Yabanc1 Dil Politikası" http://www.onlinearabic.net/sizden_gelenler_dosya (accessed: Dec. 19, 2020).

[20] H. Taymaz, Anadolu Teknik ve Meslek Liseleri. Eğitim ve Bilim, vol. 8, no. 48, 1984. http://egitimvebilim.ted.org.tr/index.php/EB/article/view/5789/1916 (accessed: Dec. 19, 2020)

[21] Milli Eğitim Bakanlığı (MEB) (2020). Denizcilik Alanı Çerçeve Öğretim Programı. MEB Yayınları. http://www.megep.meb.gov.tr/dokumanlar/Çerçeve\%20Öğretim\%20Programi/DENIZCILIK_CCOPP_10.p df http://mufredat.meb.gov.tr/Dosyalar/20191815485059-EK-1_DENIZCILIKK_CÖP.pdf http://meslek.eba.gov.tr/upload/hdc/denizcilik.pdf (accessed: Dec. 19, 2020)

[22] B. Haznedar, "Türkiye'de Yabancı Dil Eğitimi: Reformlar, Yönelimler ve Öğretmenlerimiz", in International Conference on New Trends in Education and Their Implications, Antalya, Turkey, 2010

[23] N.A. Mutua, A.B. Ouma, O.S. Atieno, "Kinetic Study of the Thermal Decomposition for Mixed Municipal Solid Waste Using Thermogravimetric Analysis," Periodicals of Engineering and Natural Sciences, vol. 5, no. 3, p. 355-363, 2017.

[24] D. Franceschi, "The Features of Maritime English Discourse," International Journal of English Linguistics, vol. 4, no. 2, pp. 78, 2014.

[25] İ. Gölbol, "Liselerdeki Denizcilik Güverte Eğitiminin Analizi ve Bir Müfredat Programı Önerisi," M.S. Thesis, Istanbul University, Istanbul, Turkey, 2018.

[26] A. Ozdöner, "Ortaöğretimde Denizcilik Eğitiminin STCW 78 Sözleşmesine Göre İncelenmesi," M.S. Thesis, Karadeniz Teknik University, Trabzon, Turkey, 2014. 